UDC378.046+378.09.

\author{
Alla V. Naidionova \\ $\mathrm{PhD}$ (Pedagogy), associate professor of the Department of English for Technical and Agrobiological Specialities \\ National University of Life and Environmental Sciences of Ukraine, Kyiv, Ukraine \\ polilanguage@meta.ua
}

Oksana G. Ponomarenko

$\mathrm{PhD}$ (Pedagogy), associate professor of the Department of English for Technical and Agrobiological Specialities National University of Life and Environmental Sciences of Ukraine, Kyiv, Ukraine

kseniaponomar74@gmail.com

\title{
USE OF PODCASTING TECHNOLOGY TO DEVELOP STUDENTS' LISTENING SKILLS
}

\begin{abstract}
A wide range of English teaching and learning approaches have emerged due to information and communication technology advancement. Podcasting is one such novel tool being exploited by teachers to enhance language skills and to encourage learning outside the classroom. Research on podcasting pedagogy suggests that podcasting helps learners boost their English language skills and support areas such as grammar, pronunciation and vocabulary. This study proves that teaching listening to students by using podcasts makes it possible to increase student listening comprehension, as this technology provides students with authentic and contextual material. The findings also suggest that such listening practice should be an integral part of ESL teaching at university level.
\end{abstract}

Keywords: podcast; English as a second language; listening skills; novel technology.

\section{INTRODUCTION}

The problem setting. Podcasting is one of the powerful, emergent technological tools that have been used in education for many years. Language learning has been recognized as one of the fields to benefit from the rapid advancement in podcasting $[1 ; 3 ; 7 ; 8 ; 9]$. At its most basic level, podcasts offer language teachers and students a wide range of extra possibilities both inside and outside of the classroom. Research studies on podcasting pedagogy have already acknowledged its potentials and have documented many evidences that podcasts can greatly help develop learners' language skills, especially speaking and listening skills $[1 ; 9 ; 10 ; 13 ; 14]$. As A. A. Garvalho et al. state, podcasts can be used for multiple purposes, such as "vocabulary revision, listening exercises, interviews with native speakers, key point summaries of a lecture or group of lectures, sharing announcements, describing homework assignment assessment, giving feedback, guidelines, reducing the effects of isolation and promoting inclusivity, developing students' study skills through collaborative learning, providing guidance on student practical work, etc." [2]. However, research specific to podcasting still remains a young and relatively undeveloped area consisting of reports on pilot studies and investigations of student perceptions. There has been a lack of empirical research. Thus the current study seeks to broaden existing research on the use of podcasting in English as a Second Language(ESL) teaching and learning.

Analysis of recent studies and publications. Podcasting has been used in a variety of ways in higher education. G. Stanley claims that podcasting can empower students by giving them opportunities to create and publish for a real audience and facilitate recording and distributing news broadcasts, developing brochures, creating or listening to teachers' notes, recording lectures distributed directly to students' MP3 players, recording meeting and conference notes, supporting student projects and interviews, and providing oral history archiving and on-demand distribution [4]. More specific to language learning, podcasting has 
several theoretical underpinnings in second language acquisition research. N.V. Grytsyk describes the didactic potential of the technology of podcast in foreign language teaching for professional purpose. The researcher claims that the use of podcasts for teaching students a foreign language for specific (professional) purposes allows to improve the teaching content, methods and organizational forms of educational process, to ensure a high scientific and methodological level of teaching, individual approach to learning and improve the effectiveness of supply of a new material [8]. Moreover, podcasts provide students with a more authentic and personal experience to develop various language skills. L. Ducate and L. Lomicka address the effect of podcasting as a tool for improving intermediate language learners' pronunciation skills. The findings demonstrated that students' pronunciation did not significantly improve, however, students responded positively to the podcasts assignment. The researchers suggest that podcasts have potential as a teaching tool, as far as student response and the ability for teacher feedback, however, direct instruction of pronunciation is necessary to impact this aspect of language learning [6]. Podcasts are also studied in relation to learning strategies. In particular, S. Ashton-Hay and D. Brookes conducted an action research aimed at finding out learning strategies of using podcasts created by students. Participants of the study created a web page in the Queensland University of Technology Blackboard Learning Management System, where the podcasts, story transcripts and student photos were uploaded. The authors concluded that the use of various types of learning strategies could facilitate language learning that can happen anywhere and anytime [3].In her study, Yu. Demianova claims that "the advancement in information and technology has revolutionized English teaching and learning approaches" [14, 56]. The researcher primarily investigates the potential of podcasts in enhancing students' interest in learning English, however, little attention is paid to boosting their listening and speaking skills. V. Khaschovyi focuses his interest on using podcasts for developing students' listening skills and proposes the collection of interesting resources for students of different levels [13]. However, the researcher doesn't analyze the effect of using this technology on listening comprehension of students making only general conclusions. According to N.V. Kardashova, "podcasts provide innovative educational opportunities and new creative environment for teaching and learning foreign languages" $[9,177]$. The author provides the features of typical educational podcasts and describes educational opportunities of this technology for teaching and learning foreign languages. Thus, the analysis of recent studies on podcasts reveals the lack of sufficient amount of research on this novel learning tool in the Ukrainian context, compared to those existing in the foreign literature. Our study aims to fill this gap and to make a contribution towards investigating the effect of podcasting on students' listening skills at the university level.

The purpose of this article is to systematize the theoretical and applied experience of podcasting use for language education; to emphasize the educational advantages of using podcasts in developing ESL listening skills; to confirm the hypothesis that listening skills of students will develop to a greater extent as a result of using podcasting technology. The findings of this study will be helpful for students, teachers, stakeholders, and researchers to adopt this innovative technology for ESL learning and teaching.

\section{METHODS OF THE STUDY}

The study employs a number of general scientific methods (analysis, synthesis, comparison, generalization) as well as highly specialized. The method of literature review is used to summarize educational experience of podcasting use in teaching and learning ESL. Methods of observation and pedagogical experiment are used for close examination of podcasting technology effect for developing listening skills in the first year students of the 
Mechanical and Technology Faculty at the National University of Life and Environmental Sciences of Ukraine. The total number of students engaged in this study is 102. The statistical analysis of data obtained confirms successful outcomes of the podcasting technology application in enhancing listening skills.

\section{THE FINDINGS OF THE STUDY}

The term podcast is a combination of the terms pod (i.e., from the Apple iPod) and broadcast [11]. Podcasting can support principles advocated by several theories of learning, such as the use of authentic materials, informal and lifelong learning, the use of learning objects for the provision of learning materials and just in time teaching [12]. Podcasting has the potential to support and promote a wide range of alternative teaching and learning approaches across all stages of the curriculum in a wide range of contexts and in different locations. According to G. Stewart, teachers might use podcasting to:

- promote personalised and independent learning;

- engage and motivate pupils;

- promote creativity in the classroom;

- create differentiated materials that can be matched to the abilities, needs and motivation of different pupils [5,9].

A closer look at podcasting as an ESL learning tool reveals the following benefits:

1. Most podcasts are free.

2. Transcripts are available for some podcasts.

3. There are thousands of podcasts to choose from on a wide range of topics.

4. User-friendly podcast aggregators are widely available.

5. Podcasts can be automatically downloaded for routine listening.

6. Podcasts present authentic topics at natural speed.

7. Plenty of podcasts are designed for English language learners.

8. Students can build up their own library and share their favourite podcasts with others.

9. Listening to podcasts promotes self-instruction.

10. The technology tunes into where today's generation of learners are [1].

A taxonomy of podcast may help teachers create and use podcasts in their classrooms. Based on literature review, a podcast taxonomy that has six variables has been developed [2]. The taxonomy is presented in Table 1 below.

Table 1

Podcast Taxonomy

\begin{tabular}{|c|c|c|c|c|c|}
\hline \multicolumn{7}{|c|}{ Podcast Taxonomy } \\
\hline Type & Medium & Length & Author & Style & Purpose \\
\hline Informative & Audio & Short & Lecturer & Formal & Inform \\
\hline $\begin{array}{l}\text { Feedback/ } \\
\text { Comments }\end{array}$ & Video & Moderate & Student & Informal & Analyze \\
\hline Guidelines & - & Long & Other & - & Develop \\
\hline $\begin{array}{l}\text { Authentic } \\
\text { Materials }\end{array}$ & - & - & - & - & Motivate \\
\hline
\end{tabular}

The four types of podcast include Informative (it presents concepts, analysis, synthesis, description of tools or equipments, reading of excerpts/poems, etc.); Feedback/Comments (to students' assignments and group work); Guidelines (to field work and to practical work; recommendations about studying, group dynamics, reflective learning etc.), and Authentic materials,i.e.materials created for the public and not for a specific course or students, such as 
interviews, news, radio programming, etc. Audio podcast is the most common, and gaining popularity podcast, which combines images and audio. Video podcast is also mentioned as vodcast, and if it is a screen captured with audio, it is called screencast. As to the length of podcasts, they distinguish Short (1-5 minutes), Moderate (6-15 minutes) or Long (>15 minutes) podcasts. However, podcasts should not take more than 15 minutes since long podcasts generally cause a loss of attention and a subsequent decrease in comprehension [2].The author can be as follows: Lecturer, Student, and other (experts, local community, and representatives). Style (Formal or Informal) is related to the degree of formality adopted. To make podcasts more interesting, they may incorporate informal learning content such as people's experiences, opinions, etc. The purpose is actually what students will learn using a particular podcast described as an action verb (inform, analyze, develop, motivate, mediate for reflective learning, etc.) [2].

English language podcasts cover a wide range of subject matter. In her study, O. Widiastuti reveals a number of content types of podcasts that provide conventional listening comprehension practice (summarised in Table 2 bellow).

Table 2

Content types of podcasts

\begin{tabular}{|l|l|}
\hline \multicolumn{1}{|c|}{ Type } & \multicolumn{1}{c|}{ Example } \\
\hline Comprehensive & http://www.englishteacherjohn.com/podcast/ \\
\hline Whole lessons & http://www.breakingnewsenglish.com/ \\
\hline Vocabulary, idioms, etc. & http://englishteacherjohn.com/ \\
\hline Conversations with script & http://www.e-poche.net/ \\
\hline Jokes & http://www.manythings.org/jokes/ \\
\hline Songs & http://englishpodsong.blogspot.com/ \\
\hline Phonetics, pronunciation & http://phoneticpodcast.com/ \\
\hline Stories & http://www.englishthroughstories.com/ \\
\hline Listening comprehension & http://mylcpodcasts.blogspot.com/ \\
\hline
\end{tabular}

Since listening is the most important component in the overall English competence and the most widely used language skill, it deserves particular attention. Listening is always used in conjunction with the other skills of speaking, reading and writing. Podcasts can be effectively used for the purpose of motivating student interest in listening to English, and providing them with exposure to native speakers' speech in authentic contexts.

For our experiment, we chose 4 groups of the first year students of the Mechanical and Technology Faculty at the National University of Life and Environmental Sciences of Ukraine. The participants were 18-20 years old and their level of English was upper Intermediate. Using podcasts for this age group is especially beneficial as it helps equip students with the skills, experiences and aspirations needed to succeed in professional life. Students present in groups A $(n=24)$ and $B(n=23)$ were chosen as experimental groups and underwent a series of podcast sessions during the autumn semester. Groups A1 $(n=22)$ and B1 $(n=23)$ formed control groups. Before the experimental study started, all the four groups had a listening test and revealed relatively similar results. At the end of the semester all four groups had a final listening test to find their level in listening. According to the podcast taxonomy described above, in this study we used informative and authentic podcasts (as to their type); short and moderate podcasts (as to the length); experts, local community, and representatives as to the author; both of formal and informal styles; with the purpose of motivating students' interest in listening to native English speech and enhancing their perceptive skills. 
Individual scores in the pre-experimental listening test (maximum score 50)

\begin{tabular}{|c|c|c|c|c|c|c|c|}
\hline \multicolumn{4}{|c|}{ Experimental groups } & \multicolumn{4}{c|}{ Control groups } \\
\hline \multicolumn{2}{|c|}{ Group A } & \multicolumn{2}{c|}{ Group B } & \multicolumn{2}{c|}{ Group A1 } & \multicolumn{2}{c|}{ Group B1 } \\
\hline Student & Score & Student & Score & Student & Score & Student & Score \\
\hline 1. & 37 & 1. & 38 & 1. & 39 & 1. & 36 \\
\hline 2. & 41 & 2. & 41 & 2. & 43 & 2. & 37 \\
\hline 3. & 36 & 3. & 39 & 3. & 36 & 3. & 38 \\
\hline 4. & 39 & 4. & 34 & 4. & 35 & 4. & 36 \\
\hline 5. & 40 & 5. & 44 & 5. & 45 & 5. & 40 \\
\hline 6. & 34 & 6. & 35 & 6. & 36 & 6. & 38 \\
\hline 7. & 37 & 7. & 38 & 7. & 37 & 7. & 38 \\
\hline 8. & 37 & 8. & 39 & 8. & 39 & 8. & 37 \\
\hline 9. & 42 & 9. & 40 & 9. & 41 & 9. & 42 \\
\hline 10. & 41 & 10. & 41 & 10. & 43 & 10. & 41 \\
\hline 11. & 39 & 11. & 34 & 11. & 36 & 11. & 36 \\
\hline 12. & 37 & 12. & 36 & 12. & 34 & 12. & 37 \\
\hline 13. & 37 & 13. & 37 & 13. & 38 & 13. & 37 \\
\hline 14. & 38 & 14. & 36 & 14. & 33 & 14. & 38 \\
\hline 15. & 40 & 15. & 33 & 15. & 36 & 15. & 36 \\
\hline 16. & 39 & 16. & 39 & 16. & 36 & 16. & 32 \\
\hline 17. & 38 & 17. & 36 & 17. & 38 & 17. & 37 \\
\hline 18. & 39 & 18. & 39 & 18. & 33 & 18. & 38 \\
\hline 19. & 32 & 19. & 43 & 19. & 41 & 19. & 38 \\
\hline 20. & 34 & 20. & 47 & 20. & 42 & 20. & 41 \\
\hline 21. & 39 & 21. & 39 & 21. & 37 & 21. & 38 \\
\hline 22. & 41 & 22. & 42 & 22. & 40 & 22. & 40 \\
\hline 23. & 37 & 23. & 35 & & & 23. & 37 \\
\hline 24. & 40 & & & & & & \\
\hline Average & $\mathbf{3 8 , 0 8}$ & Average & $\mathbf{3 5 , 2 1}$ & Average & $\mathbf{3 8 , 0 9}$ & Average & $\mathbf{3 7 , 7 3}$ \\
\hline & & & & & & & \\
\hline
\end{tabular}

As it is shown in Table 3, students of all groups scored relatively similar points: group A - average 38, 08; group B - average 35, 21; group A1 - average 38, 09; group B1 average 37,73 .

Table 4

Individual scores in the post-experimental listening test (maximum score 50)

\begin{tabular}{|c|c|c|c|c|c|c|c|}
\hline \multicolumn{4}{|c|}{ Experimental groups } & \multicolumn{4}{c|}{ Control groups } \\
\hline \multicolumn{2}{|c|}{ Group A } & \multicolumn{2}{c|}{ Group B } & \multicolumn{2}{c|}{ Group A1 } & \multicolumn{2}{c|}{ Group B1 } \\
\hline Student & Score & Student & Score & Student & Score & Student & Score \\
\hline 1. & 43 & 1. & 40 & 1. & 40 & 1. & 37 \\
\hline 2. & 45 & 2. & 40 & 2. & 42 & 2. & 38 \\
\hline 3. & 48 & 3. & 45 & 3. & 40 & 3. & 39 \\
\hline 4. & 47 & 4. & 40 & 4. & 36 & 4. & 37 \\
\hline 5. & 46 & 5. & 40 & 5. & 45 & 5. & 41 \\
\hline 6. & 40 & 6. & 42 & 6. & 37 & 6. & 39 \\
\hline 7. & 43 & 7. & 39 & 7. & 38 & 7. & 39 \\
\hline 8. & 44 & 8. & 43 & 8. & 39 & 8. & 38 \\
\hline
\end{tabular}




\begin{tabular}{|c|c|c|c|c|c|c|c|}
\hline 9. & 45 & 9. & 44 & 9. & 42 & 9. & 43 \\
\hline 10. & 47 & 10. & 45 & 10. & 43 & 10. & 44 \\
\hline 11. & 45 & 11. & 39 & 11. & 38 & 11. & 38 \\
\hline 12. & 44 & 12. & 39 & 12. & 36 & 12. & 38 \\
\hline 13. & 46 & 13. & 39 & 13. & 39 & 13. & 38 \\
\hline 14. & 42 & 14. & 43 & 14. & 35 & 14. & 39 \\
\hline 15. & 43 & 15. & 46 & 15. & 37 & 15. & 38 \\
\hline 16. & 44 & 16. & 47 & 16. & 38 & 16. & 35 \\
\hline 17. & 45 & 17. & 48 & 17. & 39 & 17. & 39 \\
\hline 18. & 44 & 18. & 43 & 18. & 38 & 18. & 39 \\
\hline 19. & 42 & 19. & 45 & 19. & 43 & 19. & 42 \\
\hline 20. & 43 & 20. & 48 & 20. & 44 & 20. & 44 \\
\hline 21. & 43 & 21. & 44 & 21. & 38 & 21. & 45 \\
\hline 22. & 48 & 22. & 46 & 22. & 41 & 22. & 44 \\
\hline 23. & 46 & 23. & 39 & & & 23. & 42 \\
\hline 24. & 45 & & & & & & \\
\hline Average & $\mathbf{4 6 , 3}$ & Average & $\mathbf{4 2 , 7 8}$ & Average & $\mathbf{3 9 ,} \mathbf{4 5}$ & Average & $\mathbf{3 9 ,} \mathbf{8 2}$ \\
\hline
\end{tabular}

As it is shown in Table 4, students of experimental groups revealed better results compared to control groups: group A - average 46, 3; group B - average 42, 78; group A1 average 39, 45; group B1 - average 39, 82 .

Table 5

Difference in individual scores in the pre- and post-experimental listening tests

\begin{tabular}{|c|c|c|c|c|c|}
\hline $\begin{array}{l}\text { Experimental } \\
\text { Group }\end{array}$ & Pre-test & Post-test & $\begin{array}{l}\text { Control } \\
\text { Group }\end{array}$ & Pre-test & \begin{tabular}{|l|} 
Post-test \\
\end{tabular} \\
\hline Group A & 38,08 & 46,3 & Group A1 & 38,09 & 39,45 \\
\hline Difference & \multicolumn{2}{|c|}{$+8,22$} & Difference & \multicolumn{2}{|c|}{$+1,36$} \\
\hline Group B & 35,21 & 42,78 & Group B1 & 37,73 & 39,82 \\
\hline Difference & \multicolumn{2}{|c|}{$+7,51$} & Difference & \multicolumn{2}{|c|}{$+2,09$} \\
\hline
\end{tabular}

From Table 5, it becomes clear that students of experimental groups showed better improvement in listening skills compared to control groups: group A - difference +8, 22; group B - difference +7, 51; group A1 - difference +1, 36; group B1 - difference +2, 09 .

This experimental study showed what effect a one semester programme of using podcasting technology had on the development of students' listening skills. The hypothesis that listening skills of students will develop to a greater extent as a result of using podcasting technology was confirmed. The difference between the pre-experimental listening test and post-experimental listening test scores in the experimental group was statistically significant, and so was the difference in the gain between the experimental and control groups. However, we need to be cautious in making conclusions from the data obtained. It is necessary to bear in mind that the study was conducted with a small sample, over a short period of time.

Based on our research, we have found it useful to emphasize the following tips for the students to help them improve their ESL comprehension skills:

- you can listen to English podcasts on a daily basis;

- you need to listen to English podcasts every day for 10-15 minutes in order to improve your listening skills and build your vocabulary;

- if needed, you can stop and start a podcast and look up words as you go. You can also use the transcript in front of you and read along; 
- there are many free podcasts on various topics. You can search through the podcast archives to find topics that interest you;

- when you find audio content that you like, listen more than once to the same audio material. While listening for meaning, try to focus on the phrases and vocabulary that you have discovered. This will help the brain retain these expressions and improve your listening skills.

\section{THE CONCLUSIONS AND PROSPECTS OF FURTHER RESEARCH}

Numerous studies on podcasting reviewed in this paper make it clear that using podcast is more beneficial and effective than using the traditional chalk and talk method and confirm the efficacy of information and technology applications in ESL learning and teaching contexts, and claim that the integration of podcasting can improve academic performance, enhance motivation, and promote learning. Teaching listening to students by using podcasts makes it possible to increase student listening comprehension as this technology provides students with authentic and contextual material. This study was conducted with a small sample of 102 university students; nevertheless the findings indicate the value of podcasting use in enhancing listening skills and suggest that such listening practice should be an integral part of ESL teaching at university level. The further experimental studies of using podcasts in ESL teaching and learning can be promising and highly advisable. It would be essential to experimentally study the effects of this novel technology on enhancing speaking skills and such important areas as grammar and pronunciation.

\section{REFERENCES}

[1] A. Hazell. "The Power of Podcasts: A Tool to Improve Listening Skills and Empower Learners". Available: https://www.academia.edu/5123544/The_Power_of_Podcasts_A_Tool_to_Improve_Listening_Skills_and _Empower_Learners (in English).

[2] Ana A. Carvalho, Cristina Aguiar, Henrique Santos, Lia Oliveira, Aldina Marques, RomanaMaciel. "Podcasts in higher education: students' and lecturers' perspectives". Available: http://repositorium.sdum.uminho.pt/bitstream/1822/10080/1/WCCE2009_pap43\%20Carvalho\%20et\%20al.pdf (in English).

[3] Ashton-Hay, S., \& Brookes, D. "Here's a story: using student podcasts to raise awareness of language learning strategies", EA Journal, 26(2), p. 15-27, 2011. (in English).

[4] G. Stanley. "Podcasting: Audio on the Internet comes of age", TESL-EJ, 9(4), 2016. Available http://teslej.org/ej36/int.html (in English).

[5] G. Stewart. "Using podcasts in the classroom". Available: http://www.belb.org.uk/Downloads/i_epd_using_podcsts_in_the_classroom.pdf p. 9 (in English).

[6] L. Ducate, L.Lomicka. "Podcasting: An Effective Tool for Honing Language Students' Pronunciation?",Language Learning \& Technology, Volume 13, N 3, 2009, p. 66-86. Available: http://lit.msu.edu/vol13num3/ducatelomicka.pdf (in English).

[7] L. M. Glushok. "Use of podcasts and blogs in the formation of professional competence of future teachers of English" Available: http://naub.oa.edu.ua (in Ukrainian).

[8] N. V. Grytsyk. Technology of podcasting in teaching foreign language (for professional purposes)". Available: http://visnyk.chnpu.edu.ua/?wpfb_dl=9(in Ukrainian).

[9] N. V. Kardashova. "English podcasts as a source of expertise in listening of students of language departments". KNLU Bulletin. Series Pedagogy and Psychology.Issue 24, p. 176-185, 2015. (in Ukrainian).

[10] O. Widiastuti. "Enhancing Students' Listening Skill Through Podcasts". Available: http://jltpolinema.org/?p=316 (in English).

[11] Oxford Advanced Learner's Dictionary(7th ed.). Podcast. New York: Oxford University Press, 2007. (in English). 
[12] Rosell-Aguilar. "Top of the Pods - In search of a podcasting "pedagogy" for language learning", Computer Assisted Language Learning, 20(5), p. 471-492, 2016. (in English).

[13] V. Khaschovyi. "English podcasts by levels". Available: http://studway.com.ua/angliyski-podkasti-zarivnyami/(in Ukrainian).

[14] Yu. O. Demianova. "Using podcasts to enhance students' listening and speaking skills". Available: http://journals.uran.ua/apppfo(in English).

Text of the article was accepted by Editorial Team 02.12.2017

\title{
ВИКОРИСТАННЯ ТЕХНОЛОГІЇ ПОДКАСТИНГУ ДЛЯ РОЗВИТКУ ВМІНЬ АУДІЮВАННЯ СТУДЕНТІВ
}

Найдьонова Алла Володимирівна

кандидат педагогічних наук, доцент кафедри англійської мови

для технічних та агробіологічних спеціальностей

Національний університет біоресурсів і природокористування, м. Київ, України

polilanguage@meta.ua

\section{Пономаренко Оксана Григорівна}

кандидат педагогічних наук, доцент кафедри англійської

мови для технічних та агробіологічних спеціальностей

Національний університет біоресурсів і природокористування, м. Київ, України

kseniaponomar74@gmail.com

\begin{abstract}
Анотація. Унаслідок стрімкого розвитку інформаційно-комунікаційних технологій спектр методів викладання і навчання англійської мови значно розширився. Підкастинг є одним із таких нових інструментів, які активно використовуються для покращення мовленнєвих навичок i заохочення навчання поза аудиторією. Дослідження, присвячені педагогіці подкастингу, свідчать про те, що подкастинг допомагає студентам розвивати англомовні навички й уміння та удосконалювати такі сфери, як граматика, вимова та словниковий запас. Це дослідження показує, що навчання аудіювання студентів за допомогою подкастів дозволяє покращити у студентів рівень сприйняття на слух, оскільки подкаст забезпечує автентичний і контекстний матеріал. Висновки дослідження також дозволяють припустити, що така практика слухання повинна стати невід'ємною частиною викладання англійської як другої мови на рівні університету.
\end{abstract}

Ключові слова: подкаст; англійська як друга мова; уміння аудіювання; новітня технологія.

\section{ИСПОЛЬЗОВАНИЕ ТЕХНОЛОГИИ ПОДКАСТИНГА ДЛЯ РАЗВИТИЯ УМЕНИЙ АУДИРОВАНИЯ СТУДЕНТОВ}

\author{
Найденова Алла Владимировна \\ кандидат педагогических наук, доцент кафедры английского языка \\ для технических и агробиологических специальностей \\ Национальный университет биоресурсов и природопользования, г. Киев, Украины \\ polilanguage@meta.ua
}

\section{Пономаренко Оксана Григорьевна}

кандидат педагогических наук, доцент кафедры английского языка для технических и агробиологических специальностей

Национальный университет биоресурсов и природопользования, г. Киев, Украины kseniaponomar74@gmail.com

Аннотация. В результате стремительного развития информационно-коммуникационных технологий спектр методов преподавания и обучения английскому языку значительно расширился. Подкастинг является одним из таких новейших инструментов, которые активно используются для улучшения языковых навыков и поощрения обучения вне 
аудитории. Исследования, посвященные педагогике подкастинга, свидетельствуют о том, что подкастинг помогает студентам развивать англоязычные навыки и умения и совершенствовать такие сферы, как грамматика, произношение и словарный запас. Это исследование показывает, что обучение студентов аудированию с помощью подкастов позволяет улучшить у студентов уровень восприятия на слух, поскольку подкаст обеспечивает аутентичный и контекстный материал. Выводы исследования также позволяют предположить, что такая практика аудирования должна стать неотъемлемой частью преподавания английского как второго языка на уровне университета.

Ключевые слова: подкаст; английский как второй язык; умение аудирования; новейшая технология.

This work is licensed under Creative Commons Attribution-NonCommercial-ShareAlike 4.0 International License. 